KARLSSON, J. L. (1970) The rate of schizophrenia in foster-reared close relatives of schizophrenic index cases. Biological Psychiatry. 2, 285-290.

Kiyama, R., Matsui, H. \& Oishi, M. (1986) A repetitive DNA family (Sau3 family) in human chromosomes: extrachromosomal DNA and DNA polymorphism. Proceedings of the National Academy of Sciences, 83, 4665-4669.

Lehrman, M. A., Russell, D. W., Goldstein, J. L. \& Brown, M. S (1986) Exon-Alu recombination deletes 5 kilobases from the low density lipoprotein receptor gene producing a null phenotype in familial hypercholesterolaemia. Proceedings of the National Academy of Sciences, 83, 3679-3683.

MAGer, D. L. \& HENTHORN, P. S. (1984) Identification of a retrovirus-like repetitive element in human DNA. Proceedings of the National Academy of Sciences, 81, 7510-7514.

Martin, M. R., Bryan, T., RAsheed, S. \& Kahn, A. S. (1981) Identification and cloning of endogenous retroviral sequences present in human DNA. Proceedings of the National Academy of Sciences, 78, 4892- 4896.

MUsich, P. R. \& DYkes, R. J. (1986) A long interspersed (LINE) DNA exhibiting polymorphic patterns in human genomes. Proceedings of the National Academy of Sciences, 83, 4854-4858.

Paulson, K. E., Deka, N., Schmid, C. W., Misra, R., Scindler, C. Rush, M. G., KADYK, L. \& LeINWAND, L. (1985) A transposonlike element in human DNA. Nature, 316, 359-361.

Sartorius, N., Jablensky, A., Korten, A., Ernberg, G., Anker, M., COOPER, J. E. \& DAY, R. (1986) Early manifestations and first-contact incidence of schizophrenia in different cultures. Psychological Medicine, 16, 909-928.

Singer, M. \& SKowronski, J. (1985) Making sense out of LINES: long interspersed repeat sequences in mammalian genomes. Trends in Biochemical Sciences, 10, 119-122.

\section{Barking Mad}

SIR: In reply to Dr Buchanan's letter (Journal, October 1987, 151, 562-563) we report two further cases of the 'barking mad'.

Case reports: (i) A 61-year-old German divorcee was admitted after having taken an overdose of a tricyclic antidepressant. She claimed it was a "cry for help", as she could no longer cope with her "mission". She described herself as being a dog (a German Shepherd), having known this since she barked instead of coughing 6 years previously following a cold. She showed her hand as proof of canine appearance, and also claimed that the transparent plaster over her CVP insertion site was a sign of moulting.

(ii) A 24-year-old unemployed man was admitted under Section 2 of the Mental Health Act. Six months prior to admission it was noted he was becoming increasingly withdrawn, self-neglectful and uncommunicative. On presentation he was mute, apart from turning his head from side to side and making clearly recognisable barking noises. His symptoms remitted within a month of treatment with anti-psychotic medication.

Unlike Dr Buchanan, we are unable to comment on the impact of such symptoms on the diplomatic service, but wonder whether, given the overrepresentation of this fairly unusual syndrome in our hospital, it could possibly be explained by the proximity of the Newham Health District to Barking and the Isle of Dogs.

R. SCHAPIRA D. H. ROY

Goodmayes Hospital

Barley Lane

Goodmayes

Essex IG3 $8 X J$

SIR: When I was a resident in psychiatry in 1974-75 at the Leeds General Infirmary, I was called late one evening by a rather dominant sister to see a "dog" in casualty. I told her I had no veterinary qualifications, but being an animal lover I made my way to casualty in a perplexed mood. I was pointed in the direction of a room in the casualty department that normally lacked any furniture, but had a mattress where, traditionally, alcoholics and psychiatric patients were examined. I saw a young man, properly dressed, between 18-22 years of age, on the mattress on his knees and elbows. When I started my usual psychiatric interview he continuously barked loudly, just like a dog, with no other types of noises. When I persisted on questioning, he suddenly said "I am a dog" and then barked again. Obviously I could not obtain further history. As psychiatric patients were on neurology wards in Leeds General Infirmary in those days, it was difficult to admit very disturbed patients. I avoided ringing Professor Hamilton at home and managed to admit the patient to High Royds Hospital.

My impression was that he was under some kind of family conflict and stress, and the intensity and frequency of barking was reduced when he knew he was going to be admitted. I later discovered that he had no previous history and settled rapidly without much pharmacological intervention and with psychosocial support.

Barking has been described as a part of a clinical picture in patients with Tardive Tourette syndrome (Stahl, 1980), and in Gilles de la Tourette's syndrome (Abuzzahah, 1982). Involuntary noises are not uncommonly heard in patients with severe tardive dyskinesia due to the involvement of muscles of expiration. It is also not uncommon for schizophrenic and severely agitated depressives to make some strange noises. Pure barking as a clinical symptom in the absence of any other associated illness is extremely uncommon, and is most probably stress-related and under voluntary control.

Professorial Unit

K. S. VADDADI

Larundel Hospital

PO Box 101

Bundoora

Victoria 3083, Australia 